\title{
Effect of Exchange Rate Fluctuation on the Financial Performance Evaluation of Multinational Companies in Nigeria
}

\author{
Osho, Augustine E. Ph.D \\ Department of Accounting, Achievers University, P. M. B. 1030, Owo, Nigeria \\ Efuntade, Alani Olusegun \\ Procurement Unit, Office of the Vice Chancellor, Federal University, P. M. B. 373, Oye Ekiti, Nigeria
}

\begin{abstract}
The research work examined the effect of exchange rate fluctuation on performance evaluations of multinational companies in Nigeria. The objective of the study was to examine how foreign exchange affects financial performance of multinational companies in Nigeria. This Study is based on the transaction cost theory, liquidity theory, inflation theory and managerial theory of firm performance. Secondary data source was explored in presenting the facts of the situation. The secondary data were obtained from relevant literatures, Central Bank of Nigeria Statistical Bulletin and annual report of selected multinational companies in Nigeria. Data were tested using the Ordinary Least Square Linear Regression model. Findings show that exchange rate fluctuation has significant effect on performance of multinational companies in Nigeria. As a result, the study concluded that exchange rate instability affects the operations of companies in Nigeria vis-à-vis international trade with other countries of the world. It was recommended that, Multinational Companies should develop a robust foreign exchange risk management framework which will clearly show its currency risk assessment procedures and implementation of foreign exchange risk management strategy. These strategies should be monitored and adjusted regularly.
\end{abstract}

Keywords: Exchange rate, Financial Performance, Inflation rate, Interest rate, Multinationals companies, Return on Assets.

DOI: $10.7176 /$ RJFA/10-16-03

Publication date: August $31^{\text {st }} 2019$

\subsection{Introduction}

The foreign exchange market is characterized by instability and uncertainty which makes prediction of future prices challenging. These fluctuations pose a threat to importer and exporters engaged in various international businesses as they are naturally exposed to currency risks (Allayannis \& Weston, 2011). Manufacturing companies dealing with production of consumer and industrial goods in Nigeria are susceptible to potential gains and losses due to changes and fluctuations in the values and purchase prices of its raw materials that are denominated in foreign currencies. Exporting and importing from abroad expose these firms to foreign exchange risks (Azeez, Kolapo \& Ajayi, 2012).

In an international trade which involves different currencies, the inconsistency of foreign exchange rates is a potentially interesting factor that drives the level of performance of manufacturing companies as it affects their financial intermediation process (Danish, 2012). Because there is no country that is self-reliant but instead they all transact businesses with one another which makes foreign exchange rates become accessible. Thus, exchange rate is a dynamic macroeconomic variable and backbone of trade (Adetayo, 2004). Variations in exchange rate plays an important role in determination of balance of trade. Domestic currency supply changes as a result of a country's fiscal and monetary policies. Demand for currency can be influenced by a large number of factors, including interest rates, inflation, and views on impending government regulation (Berger \& Bouwman, 2010). There are number of macroeconomic and industry related factors that potentially can affect the stock returns of the companies. The continuing increases in the world trade and capital fluctuations have made the exchange rates as one of the main determinants of business profitability and equity prices (Bradley \& Moles, 2002).

Exchange rate rules in developing countries are frequently subtle and contentious, primarily a sa result of the kind of structural change required, such as reducing imports or expanding non-oil exports, which invariably imply a devaluation of the nominal exchange rate.(Bagchi, \& Chakrabarti, 2012). Such domestic adjustments, due to their short-run impact on prices and demand, are perceived as damaging to the economy. Ironically, the distortions inherent in an overvalued exchange rate regime are hardly a subject of debate in developing economies that are dependent on imports for production and consumption.

In Nigeria, the exchange rate policy has experienced significant transformation from the immediate postindependence period when the country maintained a fixed equality with the British pound, through the oil boom of the 1970s, to the floating of the currency in 1986, following the near collapse of the economy between 1982 and 1985 period (Majumdar, 2017). In each of these periods, the economic and political deliberations underpinning the exchange rate policy had huge consequences for the structural evolution of the economy, inflation, the balance 
of payments and real income. Hence, the focus of this research is to examine the effect of exchange rate fluctuation on the performance evaluations of multinational companies in Nigeria (Dada \& Oyeranti, 2012).

\subsection{Review of Literature}

\subsection{Conceptual Framework}

\subsubsection{Exchange Rate Fluctuation and financial performance}

The exchange rate is the price of a unit of foreign currency in terms of the domestic currency (Nydahl, 1999). Exchange rate serves as the basic link between the local and the overseas market for various goods, services and financial assets (Reid \& Joshua, 2004). Exchange rate is the price of one country's currency expressed in terms of some other currency. It determines the relative prices of domestic and foreign goods, as well as the strength of external sector participation in the international trade. Exchange rate regime and interest rate remain important issues of discourse in the International finance as well as in developing nations, with more economies embracing trade liberalization as a requisite for economic growth (Owolabi \& Adegbite, 2017).

Using the exchange rate, one is able to compare prices of goods, services, and assets quoted in different currencies. Exchange rate fluctuations can affect actual inflation as well as expectations about future price fluctuations (Owolabi \& Adegbite, 2017). Changes in the exchange rate tend to directly affect domestic prices of imported goods and services. Exchange rate fluctuations can affect the country's external sector through its impact on foreign trade. The exchange rate affects the cost of servicing on the country's foreign debt (Oladipupo \& Onotaniyohuwo, 2011).

Under the system of freely floating exchange rates, the value of the foreign currency in terms of the local currency, like any commodity or service being sold in the market, is determined by the forces of supply and demand. Under a fixed exchange rate system, a par value rate is set between the local currency and the foreign currency by the central bank. The par value may be adjusted from time to time (Guney, 2014).

\subsubsection{Inflation Rate and financial performance}

The central objective of macro-economic policies is to foster economic growth and to keep inflation on a low level. The word inflation rings bell in the market economics of the world. It is a problem that threatens all economics because of its undesirable effects. The problem of inflation surely is not a new phenomenon. It has been major problem of the country over the years. Inflation is a household word in many market oriented economics. Although, several people, producers, consumers, professionals, non-professional, trade unionists, workers and the likes, talk frequently about inflation particularly if the affection has assumed a habitual character yet only selected few mechanisms and consequences of inflation (Omoke, 2010). There is a high level consensus among many economist, central bankers, policy makers and practitioners that one of the fundamental objective of macroeconomic policies in both the developed and developing economics is to sustain high economic growth together with low, one-digit inflation (meaning that inflation is very low) (Chude \& Chude, 2015).

\subsubsection{Interest Rate and financial Performance}

Interest rate affects all sectors of the economy through the cost of debt and the availability of money and credit and this could affect a firm's ability to access external sources of fund. Fiscal policies affect a firm's after tax net cash flow, its cost of capital, and potentially the demand for its products, and survival. Prior to interest rates liberalization, interest rates were determined through administrative controls and after liberalization by market forces (Loto, 2012). These factors that now determine interest rates include; inflationary expectations, the real rate of interest differentials, excess liquidity and domestic and foreign interest rate differentials, i.e. when there are no restrictions on capital movements. According to Cargill (1991), there exist two approaches used to determine interest rate; liquidity funds approach and loan able funds approach. These approaches assume that the level of income and employment determined in the real section of the economy are constant.

\subsubsection{Financial Performance}

Corporate financial performance was analyzed by European Central Bank, (2010) to be the capacity of a company to generate sustainable profitability within a specified period. Profitability is a bank's first line of financial protection against unexpected losses, as it improves its equity position and improves future earnings through the investment of retained profits. Alabede (2012) argued that there are basic internal and external factors affecting banks' profitability. The internal factors among others are liquidity, capital adequacy, high operating expenses, etc., while the external determinants include macro-economic variables like financial structure, exchange rate, inflation rate, economic development, etc. Thus, these factors have resultant effect on corporate performance and investors will want to invest in a company with high level of profitability. 
2.1.5 Conceptual framework of exchange rate fluctuation on the financial performance evaluation of multinational companies in Nigeria
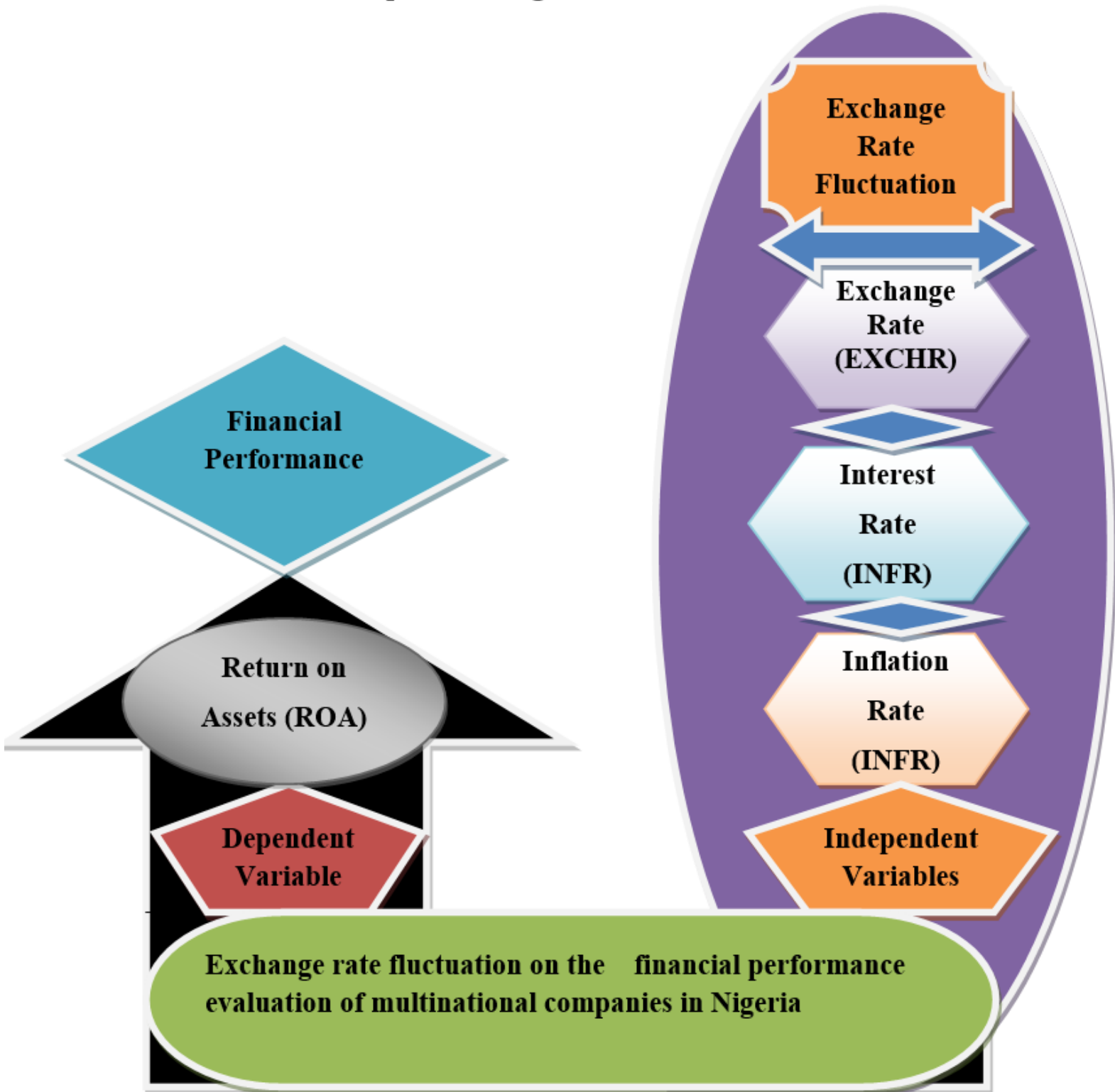

Source: Researchers' conceptual framework of exchange rate fluctuation on the financial performance evaluation of multinational companies in Nigeria Model

\subsection{Theoretical Framework}

This Study is based on the transaction cost theory, liquidity theory, inflation theory and managerial theory of firm performance.

\subsubsection{Transaction Cost Theory}

Transaction cost theory tries to explain why companies exist, and why companies expand or source out activities to the external environment. The transaction cost theory supposes that companies try to minimize the costs of exchanging resources with the environment, and that companies try to minimize the bureaucratic costs of exchanges within the company. Companies are therefore weighing the costs of exchanging resources with the environment, against the bureaucratic costs of performing activities in-house (Cargill, 1991).

A firm's interactions with the market may not be under its control (for instance statutory obligation like taxes, rate and others), but its internal allocation of resources within a firm, market transactions are eliminated and in place of the complicated market structure with exchange transactions is substituted the entrepreneur who directs production (Barro, 1992) Transaction cost theory concentrates on the relative efficiency of different exchange processes. If for the firm-as-a-production-function view the internalization of one or more stages of production might generate technological economies (that is savings on the costs of physical inputs), for the firm-as- 
organization view it could lead also to transactional economies (that is savings on the costs of exchange inputs, when reduced amounts of resources are required to get the intermediate inputs). An intermediate step between pure market exchange and vertical integration is the use of short term and long term contracts (Caroll, 1979).

\subsubsection{Liquidity Theory}

The liquidity theory looks at the interest rate as the token paid for abstinence and inconveniences experienced for having to part with an asset whose liquidity is very high. It views interest rates as a price that equilibrates the desire to hold wealth in the form of cash with the available quantity of cash, and not a reward of savings. Liquidity theory argues that the role of macroeconomic variables is to help mobilize financial resources and ensure the efficient utilization of resources in the promotion of economic growth and development (Nicholson, 2000). In relevance to the study, liquidity theory explains the role of macroeconomic variables which is to create liquidity in the economy which promotes economic activities and leads to increased profitability.

Furthermore, this theory is based on the idea that investors will hold long-term maturities only if they are offered a premium to compensate for future uncertainties, which increases with assets maturity. This theory accepts the expectations theory of the term structure of interest rates with one major qualification. Since long term securities entails less liquidity and greater market risk than short term securities, market forces normally produce a risk premium in longer term securities in the form of a higher yield (Spindt \& Tarhan, 1980).

\subsubsection{Inflation Theory}

Inflation is defined as a persistent increase in general price levels in an economy over time. Inflation effectively reduces the purchasing power of a country's currency. Low or medium levels of inflation in a country can have a positive effect on the business sector, in that it can act as an incentive to production. High levels of inflation however can harm company's profitability by affecting the cost of inputs as well as reducing final demand for its output (Faria \& Carnerio, 2001). Ultimately the effect of inflation on a firm is determined by the nature of its operations as well as its competitive environment. A firm which experiences an inelastic demand for its products may be able to cushion itself from adverse impact of inflation by transferring the price increases to final consumers, thus leaving its margin untouched. The same could be said of a company operating in a sector with low levels of competition (Okoh, \& Munene, 1986).

From liquidity point of view, inflation is likely to result in an erosion of the real value of any financial claims outstanding an opposed to the nominal value of such claims which may find it with receivables whose real value is diminished, thus inflation harms lenders and tend to benefit borrowers (Myers \& Steward, 1984). Platt and Marjorie (1995) stated that while distressed firms may prefer no growth strategy; external pressures such as inflation may cause their sales to rise exogenously and develops a new sustainable growth rate formula that describes how much growth the firm with no debt capacity can endure.

\subsubsection{Managerial Theory of Firm Performance}

This theory is based on the complex nature of the modern manufacturing sector. The theory states that the reason why managers are hired is for revenue maximization and not for profit maximization. This theory believes that for the economy to grow faster through industrialization, the country needs to increase its public expenditure so as to facilitate the developmental processes of their economies. The theory emphasizes that a firm's decisions whether to grow or not depends on the level of fiscal policy because the firm grows through government expenditure on industrialization. This is the theories of which this research is based.

Performance has been viewed from various perspectives depending on the objectives and expectations of the users of the information generated. However, it is a relationship between input and output with an objective to be achieved. Richard (2009) opined that an organization's performance can be viewed from three major areas of outcomes; financial performance (usually measured by profit, return on assets, and return on investment; Product market performance (sales and market share); and shareholders' return (total shareholder return and economic value added). Nworji (2011) elucidates that corporate performance is an important concept that relates to the way and manner in which financial resources available to an organization are judiciously used to achieve the overall corporate objectives of an organization. It keeps the organization in business and creates a greater prospect for future opportunities.

\subsection{Review of Empirical Framework}

In the work of Williams, (2018), he investigated the impact of exchange rate fluctuations on firm's performance in Nigeria. Having noted the impact of exchange rate fluctuation from the literatures, it became paramount to investigate the impact in the Nigeria context. In this study, seven research questions were formulated which led to the test of seven hypotheses. The major objective of the study was to empirically investigate the impact of exchange rate fluctuations on return of investment. The study makes use of descriptive and ordinary least square methodology. The scope of the study is 2012 to 2016 on a panel data. From the study, the exchange rate plays a significant impact on Return on Investment as most of the banks are involved in exchange rate transactions. The regression result shows that there is a positive relationship between Return on Investment and exchange rate of 145.4265. This implies that a unit increases in exchange rate of 145.4265 will bring about a rise of 145.4265 in 
Return on Investment. Since the T-calculated value in the study is 0.287 which is compared to 0.05 i.e $.287>0.05$ we reject the null and accept the alternative hypothesis that there is a significant relationship between exchange rate and return on investment (firm's performance). Other variables used in the study have a positive relationship with return on investment. In the regression result, the coefficient of determination is very high. It shows that about 67 percent of the total variations in Return on Investment (ROI) are explained by all the independent variables in the model.

Ayodele (2014) evaluated empirically the impact of exchange rate on the Nigerian economy. The study investigated how economic induces such as exchange rate and inflation rate affects changes in Gross Domestic Product (GDP) in Nigeria. The study used Secondary data collected from Annual Reports of Central Bank of Nigeria (CBN), Nigerian Stock Exchange (NSE), and Nigeria Securities and Exchange Commission (SEC) which were analyzed through the multiple regression analysis using the Ordinary Least Squares (OLS) method. The result showed that the two factors -exchange rate and inflation rate- impact significantly on the Gross Domestic Product and economic growth of Nigeria. Exchange rate has a negative impact on the GDP because as it increases, the economic growth is negatively affected, while inflation rate exerts a positive impact on GDP, indicating that firms are more willing to produce when inflation rate is high and vice versa. The outcome of the research was that the government should make Nigerian economic climate investment friendly by restoring security of lives and property, infrastructural development and improvement of local production in order to reduce the pressure on the dollar and that this would go a long way to boost the exchange rate in favour of the naira and hence improve the Gross Domestic Product.

Ebaidalla (2014) examined real exchange rate misalignment and economic performance in Sudan. The study investigates the behavior of equilibrium exchange rate and real exchange rate misalignment in Sudan over the period 1979-2009. In addition, the impact of real exchange rate misalignment on economic performance is examined. The empirical results show that the equilibrium exchange rate is significantly influenced by economic policy variables such as trade openness, government expenditure and taxes. The results also reveal that the Sudanese economy exhibited an exchange rate overvaluation over the period under consideration.

Owoeye, and Ogunmakin (2013) examined exchange rate volatility and bank performance in Nigeria. This study investigated the impact of unstable exchange rate on bank performance in Nigeria using two proxies for bank performance, namely loan loss to total advances ratio and capital deposit ratio. Government expenditure, interest rate, real gross domestic product were added to exchange rate as independent variables. The two models specified show that the impact of exchange rate on bank performance is sensitive to the type of proxy used for bank performance. Loan loss to total advance ratio shows that fluctuating exchange rate may affect the ability of lenders to manage loans resulting into high level of bad loans while capital deposit ratio does not have significant relationship with exchange rate. A core recommendation of this study is that a stable exchange rate is needed to improve the ability of the banking sector to channel credit to the economy.

In an independent study, Nnamani and David (2012) employed the symmetric and asymmetric volatility models to study the variability in the weekly exchange rate of the Naira and that of eight other currencies. With the distribution of the residual specified as normal, volatility was found to be quite persistent in seven of the series while it is explosive in one. The asymmetrical model provided no evidence of leverage effect for all the currencies.

Bala and Asemota (2013) used monthly data on Nigeria Naira exchange rate with that of three major currencies (US dollar, European Union's Euro and the British Pounds). In their study, they specified the mean equation as a constant and a dummy variable and the variance equation as standard model with the same dummy variable. The result of the fitted models showed reduction in persistence level in majority of the models.

\subsection{Methodology}

Descriptive and Ex-post facto research design was adopted for the purpose of this study. Descriptive research is the type of enquiring that deals with the collection and analysis of data for the purposes of describing and interpreting existing conditions and also to make discovery and explanation of past events. These research designs was utilized because the data needed for analysis already exist and it enables exploring relationships between two or more variables.

The data for this study was obtained from secondary sources. In order to investigate the effect of exchange rate fluctuation on performance evaluations of multinationals in Nigeria, information from Central Bank of Nigeria Statistical Bulletin and annual reports of Dangote Group Plc concerning return on assets, exchange rate, inflation rate and interest rate covering the period of years 2001- 2018 (18years) was used. Other Secondary Sources of data are relevant articles, journals and newspapers.

Ordinary Least Square technique i.e. Regression analysis was adopted to obtain interpretable findings. The relationship between exchange rate fluctuation indicators; Exchange rate (EXCHr), Inflation rate (INFr) and Interest rate (INTr) and Firms' Performance indicator; Return on Assets (ROA) were examined using linear regression model. The regression outputs were obtained using E-Views software package. 


\section{Model Specification}

The following mathematical models were developed to analyse the relationship between exchange rate fluctuation and performance evaluation of companies in Nigeria using Exchange rate (EXCHr), Inflation rate (INFr), Interest rate (INTr) as the independent variables and regressed against the dependent variable Return on Assets (ROA) used as proxy for financial performance

This study employed the model specified below.

$\mathrm{Y}_{\text {lt }}=\alpha_{\mathrm{it}}+\beta_{1} \mathrm{EXCHr}_{\mathrm{lt}}+\beta_{2} \mathrm{INFr}_{\mathrm{lt}}+\beta_{3} \mathrm{INTr}_{\mathrm{lt}}+\varepsilon_{i}$

WhereY represents the financial performance of firms in Nigeria measured by ROA

$\alpha=$ the constant term

$\mathrm{EXCHr}=$ Exchange Rate

$\mathrm{INFr}=$ Inflation Rate

$\mathrm{INTr}=$ Interest Rate

$\varepsilon=$ Error Term

In this study, the model will be modified as follows:

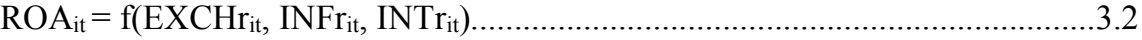

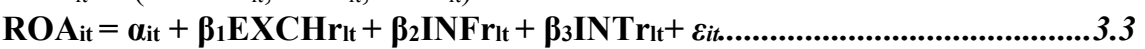

\subsection{Results and Discussion of Findings}

\subsection{Descriptive Statistics}

\begin{tabular}{lcccc}
\hline & EXCHR & INFR & INTR & ROA \\
Mean & 161.1550 & 16.87778 & 18.86667 & 0.055727 \\
Median & 149.6000 & 16.90000 & 19.25000 & 0.049609 \\
Maximum & 305.0000 & 25.00000 & 25.00000 & 0.355538 \\
Minimum & 111.9400 & 8.050000 & 15.50000 & -0.164846 \\
Std. Dev. & 56.26086 & 4.287721 & 2.422201 & 0.121625 \\
Skewness & 1.895734 & -0.337774 & 0.987704 & 0.415506 \\
Kurtosis & 5.437791 & 3.175344 & 3.851556 & 3.626374 \\
Jarque-Bera & 15.23854 & 0.365333 & 3.470537 & 0.812194 \\
Probability & 0.000491 & 0.833046 & 0.176353 & 0.666246 \\
Sum & 2900.790 & 303.8000 & 339.6000 & 1.003083 \\
Sum Sq. Dev. & 53809.84 & 312.5373 & 99.74000 & 0.251476 \\
Observations & 18 & 18 & 18 & 18 \\
\hline Source: Resear & & & &
\end{tabular}

\section{Source: Researchers' E-views Results.}

The table above shows the descriptive statistics of return on assets, exchange rate, inflation rate and interest rate covering the period of years 2001-2018. Respectively, they showed a mean of $(161.16,16.88,18.87$ and $0.055727)$, standard deviation of $(56.26,4.29,2.42$ and 0.12$)$ Skewness of $(1.896,-0.338,0.988)$, and kurtosis of $(5.438,3.175,3.852$ and 3.626$)$.

From the table, it is revealed that, over 18-year period, exchange rate has a minimum value of 111.9 and maximum value of 305.0. Its standard deviation of 56.26 is affected by the extreme value in a slightly pattern.

As revealed by the skewness, only inflation rate has negative skewness (-0.338) indicating that the degree of departure from the mean of the distribution is negative, hence, there was a consistent decrease in gross fixed capital formation from 2001-2018 in Nigeria. Though, as indicated by its Kurtosis of 3.175 which is less than 3,it shows that the degree of peakedness within the period of this study were normally distributed as most of the values do not depart from the mean. 


\subsection{Test of Hypotheses \\ Hypothesis One}

$\mathrm{H}_{0}$ : Exchange rate fluctuation has no significant effect on return on assets of firms in Nigeria.

Result of Regression Analysis

Dependent Variable: ROA

Method: Least Squares

Date: 08/13/19 Time: 17:54

Sample: 20012018

Included observations: 18

\begin{tabular}{|c|c|c|c|c|}
\hline Variable & Coefficient & Std. Error & t-Statistic & Prob. \\
\hline EXCHR & 4.880005 & 0.000586 & 0.083401 & 0.9347 \\
\hline INFR & -0.000688 & 0.008739 & -0.078785 & 0.9383 \\
\hline INTR & 0.023066 & 0.014004 & 1.647072 & 0.1218 \\
\hline $\mathrm{C}$ & -0.375702 & 0.250872 & -1.497584 & 0.1564 \\
\hline R-squared & 0.201450 & Mean dependent var & & 0.055727 \\
\hline Adjusted R-squared & 0.030332 & S.D. dependent var & & 0.121625 \\
\hline S.E. of regression & 0.119767 & Akaike info criterion & & -1.213415 \\
\hline Sum squared resid & 0.200816 & Schwarz criterion & & -1.015554 \\
\hline Log likelihood & 14.92073 & Hannan-Quinn criter. & & -1.186133 \\
\hline F-statistic & 1.177257 & Durbin-Watson stat & & 1.347878 \\
\hline Prob(F-statistic) & 0.033736 & & & \\
\hline
\end{tabular}

\section{Source: Researchers' E-views Result.}

From the regression result, the coefficient of determination $\left(\mathrm{R}^{2}\right)$ value of 0.2015 shows that, at 20 per cent, the explanatory variables explain changes in the dependent variable. This simply means that the explanatory variables explain the behaviour of the dependent variable at 20 per cent. The calculated F-statistics (1.177) having significant level (0.0337) which is greater than 0.05 , level of significance implies that the model is significant. The Durbin-Watson (DW) as shown in the regression analysis is 1.3478. From this, it shows that there is the presence of autocorrelation.

In order to obtain the regression result, the Ordinary Least Square (OLS) technique with the help of the Econometric Views (E-views) software was used. The result obtained from the regression shows that there is positive but insignificant impact of exchange rate on return on asset with a co-efficient of 4.88005 . Hence, exchange rate is positively insignificant to financial performance of firms in Nigeria.

Also, the regression result shows that inflation rate has a negative impact on return on assets with a coefficient of 0.000688 . The coefficient of inflation rate is statistically insignificant as shown by both the corresponding standard error and t-values. Thus, cumulative inflation rate is inelastic to return on assets. This negativity of the coefficient conforms to the economic a priori expectation of a negative impact of inflation rate on performance evaluation of firms. Furthermore, the result obtained from the regression shows that interest rate has a positive impact on return on assets. This is indicated in its positive coefficient of 0.023066 . However, interest rate is elastic to Gross Domestic Product since the standard error and t-values revealed that the coefficient is statistically significant.

The F-statistics showed overall significance of the regression model. F-sig. level of .033 which is less than 0.05 suggests that the null hypothesis which states "Exchange rate fluctuation has no significant effect on return on assets of firms in Nigeria" is not true. Therefore, exchange rate fluctuation has significant effect on performance evaluation of multinationals in Nigeria

\subsection{Conclusion}

The Ordinary Least Square (OLS) regression analysis was carried out, to determine the effect of exchange rate fluctuation on performance of multinationals in Nigeria. Hence, return on assets (ROA) was regressed on Exchange rate $(\mathrm{EXCHr})$, Inflation rate (INFr) and Interest rate (INTr). The overall regression results showed that exchange rate fluctuation has significant effect on performance of multinational companies in Nigeria. As a result of this, it was concluded that exchange rate instability affects the operations of companies in Nigeria vis-à-vis international trade with other countries of the world.

Based on the above, it was recommended that;

Multinational Companies should develop a robust foreign exchange risk management framework which clearly shows its currency risk assessment procedures and implementation of foreign exchange risk management strategy. 
These strategies should be monitored and adjusted regularly. The companies should emphasize the use of currency risk transfer strategies through hedging, insurance and diversification of foreign currency. Some of commonly used hedging techniques include use of currency future markets, forward markets and currency swaps.

The study further recommended that firms should explore avenues to enhance capacities for managing foreign currency risk through organizing regular trainings on currency risk management. This can be done through short term training to senior finance managers on ways of identifying, measuring and handling of foreign exchange risk. The training should not only cover exchange risk management but should also handle practical challenges facing multinational corporations and firms with international undertakings.

\section{References}

Adetayo, J. O. (2013). Management of Foreign Exchange Risks in a Selected Commercial Bank, in Nigeria, Journal of Social Science, 8(3), 207-213.

Alabede, J. O. (2012). The Intervening Effect of Global Financial Condition on the Determinants of Bank Performance: Evidence from Nigeria. Accounting and Finance Research, 1 (2), 161-176.

Allayannis, H. \& Weston, M. (2011).The Role of foreign direct investment in Economic Development: A Study of Nigeria. World Journal of Entrepreneurship, Management and Sustainable Development, 6(1), $203-251$.

Ayodele, T. D. (2014). An Empirical Evaluation of the Impact of Exchange Rate on the Nigeria Economy Journal of Economics and Sustainable Development, 5(8)

Azeez, B. A, Kolapo, F. T \& Ajayi, L. B., (2012). Effect of exchange rate volatility on macro-economic performance in Nigeria. Interdisciplinary Journal of contemporary Research in Business, 4(1), 149 -155.

Bagchi, B. \& Chakrabarti, J. (2012).Modeling liquidity management for Indian FMCG firms.International Journal of Commerce and Management, 2(4), 334-354.

Bala, D. A. \& Asemota, J. O. (2013). Exchange-Rates of Volatility in Nigeria: Application of GARCH Models with Exogenous Break. CBN Journal of Applied Statistics,4 (1), 89 - 116.

Barro, R. J. (1990). Government spending in a simple model of endogenous growth, The Journal of Political Economy, 98(5) 28-37.

Berger, A. \& Bouwman, C. (2010). How does capital affect bank performance during financial crises? Wharton Financial Working paper, 11-22.

Bradley, K. \& Moles, P. (2002) Managing Strategic Exchange Risk Exposure- Evidence from UK Firms, Managerial Finance, 5(28), 29-39.

Cargill, T. F. (1991). Money the financials system and monetary policy.(4th edition).New Jersey, Prentice Hall Inc. 2(758).

Carroll, A. (1979). A three dimensional model of corporate performance.Academy of Management. 5(27).

Chude, D. I \& Chude, N. P. (2015). Impact of inflation in Nigeria (2000-2009). International Journal of Business and Management Review 3(5), 26-34.

Dada, E. A. \& Oyeranti, O. A. (2012). Exchange rate and macroeconomic aggregates in Nigeria. Journal of Economics and Sustainable Development, 3(2), $93-101$.

Danish, M. (2012). Price discovery in Indian commodity futures market: an empirical exercise. Journal of trade and global markets, 5 (1) 23-29.

Ebaidalla, E. M, (2014). Real exchange rate misalignment and economic performance in Sudan, African Review of Economics and Finance, 6(2)

European Central Bank, (2010). Beyond Return on Equity - How to Measure Bank Performance: Appendix to the Report on EU Banking Structures. Retrieved from https://www.ecb.europa.eu/pub/pdf/other/beyondroehowtomeasurebankperformance201009en.pdf?186ec63 2b33cc504fbd295de0b425d5b on 28th January, 2016.

Faria, J. R. \& Carneiro, F. G. (2001). Does High Inflation Affect Growth in the Long and Short-run? Journal of Applied Economics, 4(1): 89-105.

Guney, Y. (2014). The Effect of Hedging on Firm Value and Performance: Evidence from the Non-financial UK Firms: Hull University Business School.

Loto, M. A (2012). Global economic downturn and the manufacturing sector performance in the Nigerian Economy. Journal of Emerging Trends in Economic and Management Sciences (SETMS) 7, (72) 224-229.

Majumdar, S. K. (2017). The Impact of Size and Age on Firm Level Performance: Some Evidencefrom India,Review of Industrial Organization, 12(2), 231-241.

Myers, S. C. \& Majiluf, N. S. (1984). Corporate financing and investment decisions when firms have information investors do not have. Journal of Financial Economics 12(94).

Nicholson, W. (2000). Intermediate microeconomics and its application, (8th ed.) Forth Worth: The Dryden Press.

Nnamani, C. N. \& David, R. O. (2012).Modelling Exchange Rate Volatility: The Nigerian Foreign Exchange Market Experience. LAP Lambert Academic Publishers, GmbH \& Co, Germany.

Nworji, I. D. (2011). Corporate governance and bank failure in Nigeria: issues, challenges and opportunities. 
Research Journal of Finance and Accounting 2(2) 72-86

Nydahl, S. (1999). Exchange Rate exposure, Foreign Involvement and currency hedging of firms: Some Swedish evidence, European Financial Management5, 241- 257.

Okoh, P. E. \& Munene, J. C. (1986).The organization dynamics, environment size, managerial values and decision Choice, International management journal 14(8).

Oladipupo, A. O \& Onotaniyohuwo, F. O. (2011). Impact of exchange rate on balance of paymentin Nigeria.African research review: An international multidisciplinary Journal, Ethiopia, 5(4), 73 - 88.

Omoke, P. C. (2010). Inflation and Economic Growth in Nigeria.Journal of Sustainable Development, 3 (2) 159 166.

Opaluwa, D., Umeh, J. C., \&Ameh, A. A. (2012).The effect of exchange rate fluctuations on the Nigerian manufacturing sector.African Journal of Business Management, 4(14), 2994 -2998.

Owoeye, T. \& Ogunmakin, A. A., (2013). Exchange rate volatility and Bank Performance in Nigeria, Asian Economic and Financial Review, Asian Economic and Social Society,3 (2), 178-185.

Owolabi, A. U. \& Adegbite, T. A. (2017). The effect of foreign exchange regimes on industrial

growth in Nigeria. Global Advanced Research Journal of Economic, Accounting and Finance,1(1), $1-8$.

Platt, H. D., \& Marjorie, B., (1995). Sustainable growth rate of forms in financial distress, Journal of Economics and Finance 19(8), 91-128.

Reid, W. \& Joshua, D., (2004).The Theory and Practice of International Financial Management. Upper Saddle River, NY: Prentice Hall.

Reid, W \& Joshua, D. (2004) The theory and Practise of International Financial Management. Prentice Hall of India.

Richard, P. J. (2009). Measuring organizational Performance: Towards Methodological Best Practices.Journal of Management, 35(718-804).

Spindt, D. A. \& Tarhan, V. (1980). Liquidity structure adjustment behaviour of large money centre banks. Journal of Money, Credit and Banking; 17(2):198 - 208.

Williams, H. T., (2018). An empirical investigation of the impact of exchange ratefluctuations on firm's performance in Nigeria.Journal of Business Management and Economic Research, 2(3), 1-10. 